\title{
Splenic abscess as a rare presentation of blastomycosis
}

\author{
Htay Phyu, ${ }^{1}$ Takaaki Kobayashi 지, ${ }^{1}$ Bradley Ford, ${ }^{2}$ Ilonka Molano ${ }^{1}$
}

${ }^{1}$ Internal Medicine, University of lowa Hospitals and Clinics, lowa City, lowa, USA

2Pathology, University of lowa Hospitals and Clinics, lowa City, Iowa, USA

\section{Correspondence to Dr Htay Phyu; htayphyu26@gmail.com}

Accepted 27 January 2020

\section{DESCRIPTION}

An 18-year-old man with no significant medical history was admitted to an academic medical centre in the state of Iowa, USA, with a 1-day history of left upper quadrant abdominal pain and fever. Seven months prior to the admission, he developed cough, fever and malaise and involuntarily lost $14 \mathrm{~kg}$. A few weeks prior to the onset of symptoms, he was digging holes in cities near the Mississippi River. $\mathrm{He}$ was given oral antimicrobials for presumptive diagnosis of community-acquired pneumonia .Follow-up chest CT in 2 months demonstrated left lower lung consolidation with a possible small focus of cavitation. Bronchoscopy showed chronic interstitial inflammation. Transbronchial biopsy showed no malignant cells and cultures were negative. At 5 months he was asymptomatic and CT demonstrated improved consolidation. On admission, his temperature was $38.3^{\circ} \mathrm{C}$ and heart rate was $112 /$ min. Physical examination revealed palpable spleen and tenderness over left upper quadrant. Laboratory tests revealed white cell count of $10.4 \times 10^{9} / \mathrm{L}$, haemoglobin of $125 \mathrm{~g} / \mathrm{L}$ and platelet count of $201 \times 10^{9} /$ L. Liver function tests were normal. CT abdomen showed splenomegaly with a large multiloculated septated lesion measuring $10.7 \mathrm{~cm} \times 5.5$ $\mathrm{cm}$ (figure 1A,B).Ultrasound-guided needle aspiration obtained $10 \mathrm{cc}$ of purulent fluid. Calcofluor white staining of the aspirate was positive for yeast forms consistent with Blastomyces dermatitidis, which subsequently grew in culture(figure 2). Serum and urine blastomyces antigen were positive at $0.59 \mathrm{ng} / \mathrm{mL}$ and $0.8 \mathrm{ng} / \mathrm{mL}$, respectively. Itraconazole was started with a plan to treat for 1 year. Two weeks later, the patient reported improvement in symptoms. At 4-month follow-up, he was asymptomatic and felt back to baseline. Urine blastomyces antigen was $<0.2 \mathrm{ng} / \mathrm{mL}$ and serum blastomyces antigen was undetectable after 4 months of therapy.

Blastomycosis is caused by dimorphic fungus $B$. dermatitidis and infection begins with inhalation of spores of $B$. dermatitidis. Blastomycosis is endemic

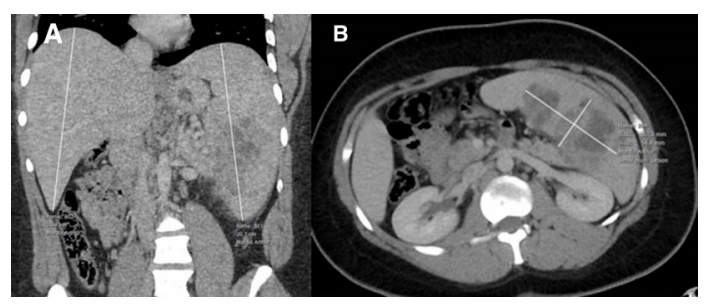

Figure $1 \quad(A, B) C T$ abdomen and pelvis showing hepatosplenomegaly seen in the coronal plane and large multiloculated septated splenic lesion.

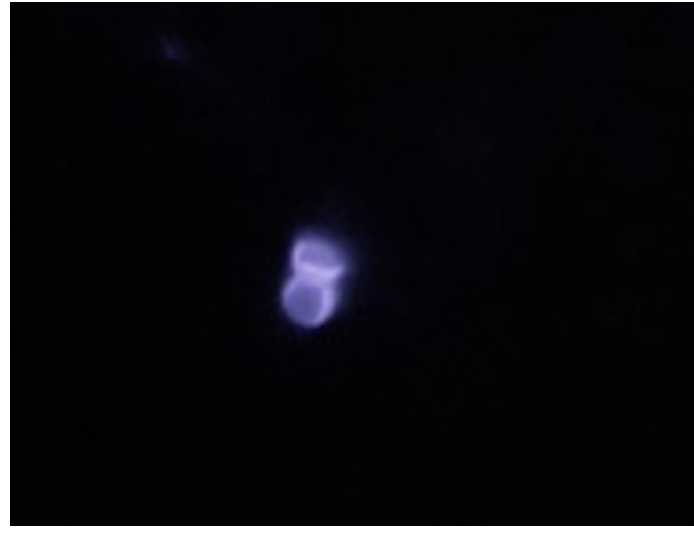

Figure 2 Calcofluor white fluorescent stain of the primary splenic aspirate, demonstrating a large (8-10 $\mu \mathrm{m}$ ) round yeast that is budding on a broad base. Most yeast in this case demonstrated shearing and crush artefacts from the small needle used for the aspiration. The monotonous large size of the yeast (others not shown were essentially identical) distinguishes Blastomyces from Cryptococcus, which can individually look similar and may also disseminate, but is more pleomorphic in size between yeast and does not demonstrate cross-reactivity with the blastomyces antigen test.

in the Mississippi and Ohio River Valleys, Great Lakes region and the St. Lawrence Seaway. ${ }^{1}$ Risk factors include living in or travelling to endemic area, activities involving disruption of soil, such as clearing brush or cutting trees; and water activities such as canoeing, boating or fishing. Symptoms of blastomycosis are varied and range from subclinical infection to fatal systemic disease. Blastomyces most commonly involves the lungs. The second

\section{Learning points}

- Blastomycosis is a systemic pyogranulomatous infection, most commonly reported in North America, that is diagnosed by culture, antigen testing and histopathology.

- Risk factors include living in or travelling to endemic area, activities involving disruption of soil, such as clearing brush or cutting trees, and water activities such as canoeing, boating or fishing.

- Although rare, blastomycosis should be considered as one of differential diagnosis in patients with splenic abscess who have a history of travel or residence in a region endemic for Blastomyces dermatitidis. 
most common manifestation after pneumonia is skin disease, and splenic abscess due to blastomycosis has been rarely reported. ${ }^{2}$ Though definitive diagnosis requires growth of the organism from the affected site, this process can take weeks. Staining of round yeast approximately $8 \mathrm{~mm}$ in diameter, budding on a broad base, is helpful from direct samples and the detection of blastomyces antigen in serum and urine has proven useful in rapid diagnosis. Its sensitivity is reportedly 93\%, whereas the specificity is reported $79 \%$ due to cross-reactivity with histoplasma. ${ }^{3}$ In addition, antigen levels decline with successful treatment and increase with recurrence. Treatment is recommended for all patients with symptomatic blastomycosis. Oral itraconazole is recommended for mild to moderate disseminated extrapulmonary blastomycosis and amphotericin B is recommended for moderately severe to severe disease. ${ }^{4}$ Treatment duration is based on site, severity of infection and immune status of the patient. In general, mild to moderate disease requires 6-12 months of treatment, and severe disease requires at least 12 months of treatment.
Contributors HP wrote the first draft of the manuscript and TK, BF and IM critically reviewed and revised the manuscript. All authors read and approved the final paper.

Funding The authors have not declared a specific grant for this research from any funding agency in the public, commercial or not-for-profit sectors.

Competing interests None declared.

Patient consent for publication Obtained.

Provenance and peer review Not commissioned; externally peer reviewed.

\section{ORCID iD}

Takaaki Kobayashi http://orcid.org/0000-0003-4643-4798

\section{REFERENCES}

1 Castillo CG, Kauffman CA, Miceli MH. Blastomycosis. Infect Dis Clin North Am 2016;30:247-64.

2 Al-Nassar S, Macnair T, Lipschitz J, et al. Blastomycosis presenting as multiple splenic abscesses: case report and review of the literature. Can J Infect Dis Med Microbiol 2010;21:53-6.

3 Wheat J, Wheat H, Connolly P, et al. Cross-reactivity in Histoplasma capsulatum variety capsulatum antigen assays of urine samples from patients with endemic mycoses. Clin Infect Dis 1997;24:1169-71.

4 Chapman SW, Dismukes WE, Proia LA, et al. Clinical practice guidelines for the management of blastomycosis: 2008 update by the infectious diseases Society of America. Clin Infect Dis 2008;46:1801-12.

Copyright 2020 BMJ Publishing Group. All rights reserved. For permission to reuse any of this content visit

https://www.bmj.com/company/products-services/rights-and-licensing/permissions/

BMJ Case Report Fellows may re-use this article for personal use and teaching without any further permission.

Become a Fellow of BMJ Case Reports today and you can:

- Submit as many cases as you like

- Enjoy fast sympathetic peer review and rapid publication of accepted articles

- Access all the published articles

Re-use any of the published material for personal use and teaching without further permission

Customer Service

If you have any further queries about your subscription, please contact our customer services team on +44 (0) 2071111105 or via email at support@bmj.com.

Visit casereports.bmj.com for more articles like this and to become a Fellow 